\title{
Adverse selection and growth under IMF programs
}

\section{Citation}

Bas, Muhammet A., and Randall W. Stone. 2013. "Adverse Selection and Growth Under IMF Programs." The Review of International Organizations 9 (1) (September 21): 1-28. doi:10.1007/ s11558-013-9173-1.

\section{Published Version}

doi:10.1007/s11558-013-9173-1

\section{Permanent link}

http://nrs.harvard.edu/urn-3:HUL.InstRepos:22547790

\section{Terms of Use}

This article was downloaded from Harvard University's DASH repository, and is made available under the terms and conditions applicable to Open Access Policy Articles, as set forth at http:// nrs.harvard.edu/urn-3:HUL.InstRepos:dash.current.terms-of-use\#OAP

\section{Share Your Story}

The Harvard community has made this article openly available.

Please share how this access benefits you. Submit a story.

Accessibility 


\title{
Adverse Selection and Growth under IMF Programs
}

\author{
Muhammet A. Bas* \\ Department of Government \\ Harvard University \\ Email: mbas@gov.harvard.edu \\ Randall W. Stone ${ }^{\dagger}$ \\ Department of Political Science \\ University of Rochester \\ Email: randall.stone@rochester.edu
}

Keywords: IMF, Growth, Strategic statistical models

Classifications: C3, F3, Q4

\begin{abstract}
The dominant approach to studying the effects of IMF programs has emphasized moral hazard, but we find that adverse selection has more impressive effects. We propose a novel strategic selection model to study the growth effects of IMF programs, which allows for the possibility of adverse selection. We find that adverse selection occurs: the countries that are most interested in participating in IMF programs are the least likely to have favorable growth outcomes. Controlling for this selection effect, we find that countries benefit from IMF programs on average in terms of higher growth rates, but that some countries benefit from participation, while others are harmed. Moral hazard predicts that long-term users of Fund resources benefit least from participating in programs, while adverse selection predicts the opposite. Contrary to previous findings, we find that IMF programs have more successful growth performance among long-term users than among short-term users.
\end{abstract}

*Department of Government, 1737 Cambridge St. CGIS N209, Cambridge, MA 02138, Phone: 617-495-4765, Fax: 617-495-0438, Email: mbas@gov.harvard.edu

${ }^{\dagger}$ Department of Political Science, Harkness Hall 336, University of Rochester, Rochester, NY 14627, Phone: 585273-4761, Fax: 585-271-1616, Email: randall.stone@rochester.edu 
Countries that face a sharp deterioration of their current accounts or a sudden stop of international financing frequently turn to the IMF for balance of payments support. In these circumstances, governments hope to avoid a costly collapse of the financial system or of domestic consumption, in the expectation that the combination of IMF financial support and economic reforms will improve economic performance. Empirical support for this expectation is mixed, however, and the literature on the effects of IMF lending is on the whole quite pessimistic. Furthermore, a number of poor countries have been involved in IMF programs for many years, and the emerging consensus both inside and outside the Fund is that these cases are even less favorable for economic growth. These observations pose a puzzle. Why do countries seek to participate in IMF programs, if their results are generally negative?

The lack of consistent econometric support for the proposition that IMF lending is beneficial is particularly striking in studies of short-run effects, which constitute a substantial portion of the literature. It is understandable that IMF lending, like development assistance in general, might be ineffective at promoting medium- or long-term growth, either because it proposes inappropriate policy adjustments, or because those policy measures reduce growth for several years before they begin to bear fruit, or because painful measures are indifferently implemented. However, the point of IMF lending is to help in the very short run. It provides an emergency stream of financing that is intended to prevent a severe economic downturn caused by a shortage of fiscal liquidity or foreign reserves. In the absence of such financing, presumably, the crisis occurs; and banking crises, sovereign defaults and currency crises are generally followed by a sharp contraction of economic activity. Meanwhile, IMF conditionality has not had time to have much effect, either positive or negative, in the same year in which a program is announced, so any short-run effect is attributable to lending rather than policy reforms. We revisit the data, focusing again on short-term effects, and suggest that the econometric analysis is at fault, rather than governments' expectations.

Scholars acknowledged the problem of selection bias in evaluating the effects of IMF programs long before they succeeded in adequately addressing it (Goldstein and Montiel, 1986). In recent studies of IMF program effects it has become standard practice to use some kind of selection cor- 
rection, whether a Heckman-type parametric selection model, an instrumental variables approach, or matching (Steinwand and Stone, 2008). Which approach is chosen is consequential, because a selection correction is only as good as the specification of the selection equation. ${ }^{1}$ We introduce an estimator for the selection stage that incorporates strategic interaction. That is, we model the government's and IMF's choices with a strategic game, and derive the likelihood function from their expected utilities. This estimator is an improvement over previous approaches in several respects. Unlike single-equation estimators, it allows for the possibility that some variables have countervailing effects; for example, making countries more eager to apply for programs but making the IMF less eager to approve them. In addition, our estimator provides a more convincing solution than previous approaches to the problem of partial observability: we observe a program when both agents assent, but when we do not observe a program, we do not know which agent withheld consent. Models with partial observability are notoriously fragile, but our strategic model is more stable, because we use the structure of the game to improve identification. Finally, the strategic model allows for strategic interaction. The government might be deterred from applying for an IMF program, for example, because it believes that a program is unlikely to be approved. ${ }^{2}$

The results of our analysis lead to three substantive conclusions. First, in contrast to prominent recent studies, we find that the average treatment effect is positive, and the majority of IMF programs have beneficial short-term effects on economic output. Although it is conventional wisdom that IMF programs lead to short-term contraction of GDP, we find that the average program is less contractionary than the counterfactual without IMF support. Second, we find great diversity among the treatment effects experienced by particular countries, and show that governments that are most eager to participate in IMF programs generally experience the least beneficial effects. Third, the effects of IMF programs are more positive, rather than less so, in countries that have

\footnotetext{
${ }^{1}$ Przeworski and Vreeland (2000) made an important advance by pointing out that initiating an IMF program requires the consent of two agents, a government and the IMF. This implies that two selection equations are needed to model the process of program approval. Przeworski and Vreeland (2000) and Vreeland (2003) use a bivariate probit model with partial observability to account for these separate decisions, and find that IMF program participation is harmful to growth when correcting for selection effects. We introduce an alternative approach, which also incorporates partial observability, but unlike Przeworski and Vreeland (2000) and Vreeland (2003), our model incorporates strategic interaction.

${ }^{2}$ Strategic interaction, in effect, introduces a series of interaction terms into the government decision equation between variables that affect government utilities and variables that affect IMF utilities.
} 
extended participation in IMF programs. These results are robust to using the data used in recent studies (Vreeland 2003) and to using a new data set that we gathered, which has broader coverage from 1970-2008.

The key implication of our analysis is that the IMF faces a problem of adverse selection (Akerlof, 1970). Countries that apply to participate in IMF programs have unobservable attributes that are correlated with their future economic performance, which might be related to the policy preferences of the government, to social instability, or to other political factors that we have not considered. For the sake of simplicity, we will refer to applicant governments as being either of a "good" or a "bad" type, where good governments are expected to promote growth and bad governments are unlikely to do so. The IMF cannot separate the worthy from the unworthy applicants, and any observable attribute that it might use to distinguish among them is correlated with the objective need for support. Meanwhile, the best candidates for successful growth are countries that choose not to apply. As a result, the pool of countries available to participate in IMF programs is skewed towards the type that is unlikely to successfully implement reforms and return to growth. Just as the best used cars are rarely offered for sale, the countries with the best growth prospects rarely approach the Fund for assistance. Those that do ask for support tend to be lemons.

Our results indicate that the poor performance of IMF programs is due to adverse selection, and that the failure to find evidence that these programs promote growth in the quantitative literature is due to the failure to adequately model this strategic selection process. We show that the countries that are most strongly interested in participating in IMF programs are in fact the least likely to grow. When we control for this selection effect, we find that IMF programs have a significant positive effect on growth. Furthermore, contrary to concerns about recidivism and long-term use of Fund resources, we find that the selection effects are mitigated and the growth effects are stronger for countries that are already participating in IMF programs. Consistent with our theory of adverse selection into IMF programs, we find that the growth effects are strongest for the countries that have participated several years. This suggests that the IMF gradually discovers the borrower's type by observing its compliance with conditionality and adjusts its programs in ways that compensate 
for the problems posed by weak governance.

\section{Moral Hazard and Adverse Selection}

The International Monetary Fund was not originally intended to promote economic growth, to engage in long-term lending, or to oversee economic reform programs. Its original purpose was to safeguard the system of fixed exchange rates foreseen under the Bretton Woods agreements by pooling resources to provide short-term balance of payments support to deficit countries. As the Fund gradually expanded its sphere of activities, however - conditionality was formally introduced in 1952, medium-term lending was established in 1974, and lending at concessional interest rates for poor countries was introduced in 1986 - it has increasingly been judged according to its success or failure at promoting economic growth. Critics argue that IMF programs in fact retard growth, either by promoting inappropriate economic policies or by creating perverse incentives. A growing concern is that long-term use of IMF resources may be particularly harmful because it creates patterns of dependency. The literature on IMF programs is replete with discouraging findings. In a review of 24 studies of the effect of IMF programs on growth published through 2000, Stone (2002) reports that only one found statistically significant results that supported the view that IMF programs promote growth; two found significant results that indicated that IMF programs retard growth; the rest were inconclusive. In a review of twelve studies published between 2000 and 2008, Steinwand and Stone (2008) find two statistically significant and positive results, seven significant negative results, and three inconclusive results. These studies use data sets with varying coverage and employ a wide range of methodological approaches, and the results are generally discouraging; however, the inconsistencies suggest that the question is far from resolved.

Reasons offered for these disheartening findings differ. A substantial body of scholarly opinion holds that IMF programs are ineffective at promoting economic recovery and laying the groundwork for long-term growth because the IMF promotes an inappropriate mix of policies. As Ngaire Woods bluntly puts it, "There is no incontrovertible evidence that the IMF and the World Bank know what is good for their borrowing countries" (Woods, 2006). Joseph Stiglitz argues that IMF conditionality 
follows a uniform pattern of macroeconomic contraction, privatization and deregulation that is inappropriate for most developing countries, and that bad economic policies are responsible for poor growth outcomes (Stiglitz, 2002). The claim that IMF conditionality follows a cookie-cutter pattern that varies little from country to country has been rejected by empirical studies, which find that it varies widely and responds to local circumstances (Ivanova et al., 2003; Gould, 2006; Stone, 2008). Nevertheless, the possibility remains that conditionality is harmful to growth. An alternative explanation for poor growth results is that conditionality is frequently not implemented. A study sponsored by the IMF found that 70 percent of IMF programs are interrupted at some point because of non-implementation (Ivanova et al., 2003). A more recent study shows that 93 percent of countries that participated in IMF programs over a decade suffered program interruptions (Stone (2011), 182). If implementation rates are low, it can be difficult to determine whether poor outcomes are due to implementing harmful conditionality or not implementing beneficial conditionality (Vreeland, 2006). In studies of short-term program effects, however, the question is largely irrelevant, because conditionality is rarely fully implemented in the same year as a program announcement, and in any case has not had time to exercise whatever influence it will ultimately have on growth rates. Short-term effects of IMF programs must be due to the effects of financial support or the reactions of capital markets.

The most prominent explanation for the negative effects of IMF programs is the problem of moral hazard. Moral hazard is an incentive problem created by insurance: if agents do not pay for the consequences of their actions because they are insured, they have weak incentives to mitigate risk. Concerns about moral hazard have been at the forefront of policy briefs that have called for reining in the Fund and restricting its activities to short-term balance of payments lending rather than long-term development and structural adjustment lending (Hills, Peterson and Goldstein, 1999; Meltzer, 2000). If countries can rely upon the IMF as a second source of financial reserves and capital market participants come to believe that certain countries are "too big to fail" - as was often claimed for Russia and Argentina until they did fail - the incentives for governments to pursue sensible fiscal policies are weakened. Capital flows to risky countries in spite of their weak fundamentals because a rescue is expected if the investment climate turns stormy. This, in 
turn, becomes a self-fulfilling prophecy. Indeed, the debates within the Fund about how to respond to crises always balance a concern for containing financial instability with a concern about not promoting moral hazard. During the Mexican crisis in 1995 and the Asian Crisis in 1997, for example, IMF Staff and Executive Directors debated whether an overly aggressive response would promote moral hazard (Blustein, 2001; Copelovitch, 2010).

One version of this argument focuses on Fund support for governments that were committed to defending fixed exchange rates during the 1990s (Goldstein, 1998). Governments often face political temptations to defend currency pegs long after they might have otherwise abandoned them, because this allows them to put off policy adjustment (Cooper, 1971; Frankel, 2005; Leblang, 2005). If they defend fixed parities while simultaneously following inflationary policies, the results are overvalued exchange rates, declining competitiveness, slow growth and, eventually, a currency crisis. A supportive stance by the IMF can exacerbate the temptations to put off adjustment. A second concern is that IMF activism in promoting debt rescheduling during sovereign debt crises may encourage the unwise borrowing and lending practices that create the problem in the first place. The IMF became deeply involved in rescheduling debt during the 1980s debt crisis and the Asian Crisis of 1997, and every major debt rescheduling operation by the Paris and London Clubs is supported by an IMF program (Lipson, 1985; Aggarwal, 1996; Blustein, 2001; Copelovitch, 2010). There is a fine line to be walked between stabilizing international financial markets sufficiently to promote the free flow of capital and promoting unwise international lending by lowering its risks.

A third concern is that IMF financing may reduce the incentives for governments to solve long-term structural problems that contribute to slow growth and underdevelopment. As the IMF Independent Evaluation Office evaluation of prolonged use of Fund resources concludes, "[T]he drawbacks associated with prolonged use are sufficiently serious to warrant a greater effort to reduce its extent" (Independent Evaluation Office, 2002). Bird, Hussain and Joyce (2004) argue that repeat users of IMF resources constitute an underclass of the international system that has become a clientele dependent on the IMF. "Recidivism," as they label this phenomenon, is associated with extreme poverty, weak external accounts and high levels of foreign debt. A number of studies 
have found that countries that have used IMF programs in the past are more likely to use them again, suggesting that recidivism is a real phenomenon (Atoian and Conway, 2006; Jensen, 2004; Pop-Eleches, 2009; Sturm, Berger and de Haan, 2005). ${ }^{3}$

This paper proposes an alternative to the prevailing view. In our view, IMF programs have a wide range of observed effects, some of which promote growth, and some of which impair growth. Many of the unfavorable outcomes are caused by perverse incentives attributable to moral hazard, but the influence of these problems has been overstated because the literature has not fully appreciated the depth of the adverse selection problem the IMF faces. The participants in IMF programs differ systematically from non-participants in ways that are not easy to observe but that have significant implications for their future economic performance.

Adverse selection occurs when one partner to a transaction has private information that affects the other partner's payoff if the transaction occurs. In Akerlof's classic example, used-car sellers have better information about the value of their wares than used-car buyers. The price that buyers are willing to pay is based on their priors about this private information, so selling is unattractive to the owners of high-quality cars and attractive to the owners of low-quality cars. As a result, the distribution of quality in the cars actually offered for sale is skewed downwards, which depresses the market price. In equilibrium, therefore, mutually beneficial transactions fail to be made.

We argue that a similar problem arises in IMF programs. The potential sellers in this example are the countries that offer to implement economic reforms in return for IMF support, and the buyer is the IMF, which has difficulty separating the credible reformers from the non-credible ones. Borrowing governments have at least three information advantages over the IMF. ${ }^{4}$ First, there

\footnotetext{
${ }^{3}$ Moser and Sturm (2011, p. 317) find a different effect for the post-Cold War period. In a pooled analysis, they find a robust relationship between prior participation and continuing participation; however, in a conditional fixed-effects analysis, they find that prior participation reduces the probability of participating. This indicates that results claiming an effect of recidivism were instead capturing the underlying propensity to participate.

${ }^{4}$ The assumption of our econometric model is that there are unobservable variables that affect both government decisions to participate in IMF programs and subsequent growth performance under those programs. It is not necessary to this argument that these variables be unobservable to the IMF. The IMF might, for example, have good intelligence that the government plans to renege on its commitments, but be willing to offer support nevertheless. What is necessary to our argument is only that these variables are not observable to us as analysts, so that their effects can only be estimated, rather than controlled for. However, we argue that some of these variables are in fact unobservable to the IMF, and this accounts for the pattern of adverse selection that we identify below.
} 
are economic data that are known to the government but not to the IMF. As the peso crisis was unfolding in 1994, for example, the Mexican government delayed reporting the level of central bank reserves and the fiscal deficit to the IMF. During the 1996 presidential election, the Central Bank of Russia violated IMF conditions by secretly using its reserves, which had been placed in anonymous off-shore accounts, to support the market for government bonds. When the IMF Mission arrived in Korea in the midst of the 1997 crisis, it did not have accurate information about the level of central bank liabilities, the volume of non-performing loans in the commercial banking sector, or the foreign liabilities of Korean banks. These turned out to be the key variables that intensified the crisis, because Korean banks had borrowed heavily and lent heavily in dollars, and the central bank had pledged most of its reserves to cover their debts. Second, there are political judgments that the government can make better than an outside agency. For example, how much austerity can the Greek government sustain before it loses its margin of support in parliament? How much wage restraint can the unions be convinced to exert before they refuse to cooperate? Third, there are questions about the government's own intentions. The IMF could not know how far the de la Rúa government was willing to go in 2001 to defend its fixed exchange rate of one Argentine peso to one US dollar. The Fund could only guess what Boris Yeltsin planned to do after winning the 1996 election. Each set of factors can affect both the government's interest in participating in an IMF program and the likely effects of that program.

Returning to the used-car analogy, the price is the degree of conditionality imposed in the adjustment program. The IMF seeks to support successful economic reform programs and avoid failures, and from the IMF perspective, the risk of program failure is a function of the government's type - its level of commitment to economic reform - and of the degree of conditionality. Multiple binding policy conditions that specify detailed procedures rather than general targets increase the likelihood of identifying and preventing policy slippage, but make the program more intrusive and politically risky from the perspective of the borrower. A symptom of adverse selection arises when the IMF imposes a relatively high price of participation because it is uncertain of the type of its borrowers. If all of the Fund's borrowers were committed reformers, it could offer less constraining programs, which all of the countries would be willing to accept. Because many potential borrowers 
are not committed to reform, however, the IMF offers conditionality packages that are intrusive and constraining. This interpretation is consistent with the marked increase in conditionality that occurred in the 1980s - the average number of performance criteria climbed from 7 between 1974 and 1982 to 12 between 1983 and 1990 - as lending expanded in Africa and countries in the grip of the Latin American debt crisis drew heavily on IMF resources (Gould, 2006). Some of the committed types are unwilling to participate when conditionality is intrusive, so the distribution of borrowers is skewed towards the type of government that is not committed to implementing reform. Three factors exacerbate the adverse selection problem: enforcement problems, non-transparent financial data, and capital market expectations.

If IMF programs were enforceable contracts, it might be possible for the IMF to screen potential borrowers by offering schedules of conditionality that ensured that only committed reformers would participate. However, the IMF's only instrument to ensure compliance is to withhold installments of financing, or tranches, and it finds it difficult in practice even to do that for long. Consequently, the borrowers that find IMF conditionality most costly are the ones that actually intend to implement the promised reforms, and the ones that have no such intention find it relatively costless to agree to the IMF's terms. Rather than resolving the IMF's information problem, strategic screening exacerbates it and strengthens the tendency of the worst candidates to step forward.

Second, it might be possible to screen out the less committed if it were the case that committed reformers had greater need for IMF support than faux reformers. The opposite is the case, however. Among the key variables that are difficult for the IMF to observe are the level of usable international reserves (which potential borrowers often disguise through elaborate accounting tricks) and the vulnerability of the domestic banking sector. Poor values on these variables make borrowers highly vulnerable to international financial shocks and therefore eager to participate in IMF programs to shore up their weak external accounts. Governments that underreport their vulnerability, however, are unlikely to be committed reformers, so those countries that are more vulnerable than they seem are likely to be poor candidates for IMF programs.

Third, if committed reformers stood to gain more from participating in IMF programs than 
other countries, they might tend to apply for programs at higher rates. One such argument that the Fund routinely makes is that IMF programs represent a "seal of approval" for a government's policies, which catalyze private capital flows. By implication, the IMF has superior information that allows it to separate worthy from unworthy borrowers and convey this information to capital markets. However, to the extent that participating in IMF programs imposes a stigma on the recipient government, which is seen as surrendering a portion of national sovereignty to foreign powers, participation might be a signal of weakness: only truly desperate governments need apply. The recent quantitative literature yields a mixed verdict, with several studies finding that IMF lending does not catalyze private capital flows (Bird and Rowlands, 2002; Eichengreen, Gupta and Mody, 2006; Jensen, 2004), and others finding that it does under certain conditions (Mody and Saravia, 2006; Bauer, Cruz and Graham, 2012). It appears that in some cases, rather than representing a "seal of approval," an IMF program signals to markets that a crisis is looming. To the extent that IMF lending sends a negative signal, the best-managed countries should avoid IMF programs.

The above argument leads to three testable hypotheses. First, a selection model that allows for the possibility of strategic adverse selection should find that countries that are most interested in participating in IMF programs are the worst candidates for growth. Second, if adverse selection rather than moral hazard accounts for the negative correlation between participation in IMF programs and growth, a selection model that controls for adverse selection should show that IMF programs improve economic performance. This should particularly be the case in the short term; indeed, if IMF programs do not improve the odds of weathering financial crises on average, at least in the short term, it is hard to explain why countries vountarily participate in them. Finally, a further implication of the adverse selection view is that - contrary to the critique of recidivism - prolonged use of IMF resources should be more beneficial than short-term use, because over a longer time horizon the IMF is able to screen countries and determine which are willing to commit to policy reform, gradually mitigating the problem of asymmetric information that lies at the heart of the IMF's performance problem. 


\section{Method}

It has long been recognized that the fundamental empirical problem in assessing the effects of IMF programs is selection, although initial contributions were agnostic as to whether selection made the IMF's effects appear more or less beneficial than they really were (Goldstein and Montiel, 1986). IMF programs are not applied at random, so the sample of program participants differs in systematic ways from the sample of non-participants. This means that any comparison of the two groups may be subject to selection bias (Heckman, 1979). The effects of the bias can be mitigated by using parametric selection-correction or non-parametric matching techniques, and the choice should depend on theoretical expectations about whether selection occurs on observable or unobservable factors. A parametric approach is preferable if we have strong priors about the selection mechanism, particularly if selection is primarily on unobservable factors such as the government's commitment to reform, as argued here. Since our model provides us with expectations about the functional form of the strategic interaction between the IMF and borrowing countries, exploiting this information improves the efficiency of our estimates.

In particular, our theoretical argument is that there is selection on unobservables, which contradicts the necessary assumption for matching to provide consistent estimates. ${ }^{5}$ Furthermore, matching can be appropriate if the analyst is only interested in uncovering a treatment effect, but it does not allow the analyst to investigate the mechanism by which selection affects outcomes. Our method, in contrast, allows us to directly estimate the effects of adverse selection. Getting a consistent estimate of the effects of IMF programs net of selection is interesting, but IMF programs do not exist without selection problems, so it is really just an estimate of a counterfactual. The effects of selection are what we are theoretically and substantively most interested in, and matching cannot shed any light on those.

Our statistical model is comprised of two parts: a selection step that determines selection of observations into our sample, which takes into account the strategic interaction between a govern-

\footnotetext{
${ }^{5}$ Matching techniques rely on the assumption of strong ignorability, which means that any factors that distinguish the treatment and non-treatment groups after matching have no effect on the probability of receiving the treatment. This cannot be the case if there is adverse selection.
} 
ment and the IMF; and the outcome equation on countries' annual growth rates that takes into account non-random selection into the sample by making use of appropriate selection corrections derived from the first step. Below, we first describe the outcome equation, and then develop and discuss the selection model we use.

\subsection{Outcome Equation: Annual Growth Rate of GDP}

Given data on growth rate (Y), IMF program status (P), and a set of factors that we believe to affect growth rates $(\mathrm{X})$, the first model specification that comes to mind is:

$$
Y_{i}=X_{i} \beta+\delta P_{i}+\epsilon_{i}
$$

where $\epsilon$ is the error term capturing unobserved factors affecting growth rates of countries, normally distributed with mean zero and variance $\sigma_{\epsilon}^{2}$. This specification makes several important assumptions: first, it assumes that program status affects growth only by changing the intercept, and the effects of the other regressors are unchanged. Second, the assignment of IMF programs to countries is assumed to be random, or not correlated with the dependent variable. If these assumptions are satisfied, this model can be estimated via ordinary least squares (OLS) regression. The second assumption is likely to be violated, however, since IMF programs are not sought and signed randomly, and unobservable factors determining selection into an IMF program are likely to be correlated with unobservable factors affecting growth levels. If such a correlation exists, estimating equation 1 with OLS will result in biased estimates of the effect of IMF programs on growth. To deal with this selection problem, we model growth with a "switching regression" model described in Maddala (1983):

$$
\begin{aligned}
& Y_{1 i}=X_{1 i} \beta_{1}+\epsilon_{1 i} \text { iff } \quad P=1 \\
& Y_{2 i}=X_{2 i} \beta_{2}+\epsilon_{2 i} \text { iff } \quad P=0
\end{aligned}
$$


where $Y_{1 i}$ represents the growth rate for countries that are under a program in a given year, and $Y_{2 i}$ represents growth in countries not under a program. To estimate the effect of IMF programs on growth, we need to ask the counterfactual question, "what would the growth rate of a participating country have been, had that country not participated in an IMF program?" ${ }^{6}$ We consider two alternative specifications of this counterfactual that are discussed in Maddala (1983) and Cameron and Trivedi (2005): In the first, the gross program benefit for participant $i$ can be calculated as

$$
G B=Y_{1 i}-E\left(Y_{2 i} \mid P=1\right)
$$

where we calculate the difference between the observed growth rate of a country under a program and the predicted counterfactual growth rate that would have resulted had that country not been under a program. An alternative measure, the estimated expected benefit from an IMF program for participant $i$ is

$$
E B=E\left(Y_{1 i} \mid P=1\right)-E\left(Y_{2 i} \mid P=1\right)
$$

where we calculate the predicted difference between the growth rates of the country when under and, counterfactually, not under a program.

\subsection{Sample Selection: Strategic Probit with Partial Observability}

If selection into programs is not random and is correlated with the error term of the growth equation as we argue, running two OLS regressions to estimate equations 2 and 3 will not result in accurate estimates due to selection bias. To calculate $G B$ and $E B$ accurately, we need to calculate appropriate corrections for expectations $E\left(\epsilon_{1 i} \mid P=1\right)$ and $E\left(\epsilon_{2 i} \mid P=0\right)$ that take into account non-random and strategic sample selection.

We use a parametric technique because we want to test for the presence of a particular type of selection effect: strategic adverse selection (Akerlof, 1970). The problem from the IMF's perspective

\footnotetext{
${ }^{6}$ This is the well-known treatment effects problem that has been utilized widely in the econometrics literature, and discussed in Maddala (1983), Greene (2003), and Cameron and Trivedi (2005).
} 
is that some of the countries that it would like to support do not apply, so it never has the opportunity to offer them support. This suggests a particular strategic form to estimate, which is illustrated in Figure 1, below. The potential borrower moves first, deciding whether to apply for IMF support or not, and applies if the expected utility of applying (and possibly being rejected) exceeds the utility of non-participation. The IMF then decides whether to approve or reject the applicant based on observable factors, conditional on its interim expectation about the set of countries that apply. ${ }^{7}$

\section{[Figure 1 about here.]}

Based on this strategic form that determines program participation, we develop a statistical strategic probit model with partial observability to model selection into our sample of IMF programs. This selection model incorporates the strategic interaction hypothesized by our theory into the likelihood function to be estimated, which should improve the efficiency of our results and remove any bias due to strategic misspecification (Signorino, 1999; Signorino and Yilmaz, 2003). We argue that a candidate government faces uncertainty about the IMF's response when deciding to seek an agreement with the IMF. Based on observable indicators of the IMF's choice, the government calculates the IMF's probability of signing an agreement, and makes a decision strategically based on its expectations about what the IMF will do. It is assumed that both the government and the IMF have utilities associated with the outcomes resulting from their choices, and the following two latent equations together determine selection into IMF programs:

$$
\begin{aligned}
G^{*} & =p_{\text {sign }} U_{G}(\text { Prog })+\left(1-p_{\text {sign }}\right) U_{G}(\text { Decl })-U_{G}(N o A p p)+\varepsilon_{G} \\
I^{*} & =U_{I}(\text { Prog })-U_{I}(\text { Decl })+\varepsilon_{I}
\end{aligned}
$$

where $\varepsilon_{G}$ and $\varepsilon_{I}$ are normally distributed random variables, ${ }^{8}$ and $p_{\text {sign }}$ is the IMF's probability of

\footnotetext{
${ }^{7}$ In practice, rejection takes the form of insisting on the adoption of performance criteria or prior actions that the borrower is unwilling to fulfill, but in that case the analyst observes only non-participation.

${ }^{8}$ We use the agent error specification of Signorino's (1999) strategic probit. To make estimated coefficients com-
} 
agreeing to a program with the government, estimated using equation 7 . A government seeks a program with the IMF if and only if $G^{*} \geq 0$. Likewise, the IMF prefers entering into an agreement with a government if and only if $I^{*} \geq 0$. The government's and the IMF's utilities are modeled with explanatory variables. As analysts, we only observe a program when both the government and the IMF are willing to sign one. In the absence of a program, we cannot know with certainty whether the government did not seek a program, or the IMF did not want to enter into a program with an interested government. Thus, to model the overall probability of no program $(P=0)$, we need to employ a partial observability model that accounts for both possibilities. In other words,

$$
\begin{aligned}
& \operatorname{Pr}(P=1)=\operatorname{Pr}\left(G^{*}>0, I^{*}>0\right) \\
& \operatorname{Pr}(P=0)=1-\operatorname{Pr}\left(G^{*}>0, I^{*}>0\right) .
\end{aligned}
$$

We can now calculate our selection corrections to be used in the growth equation. This results in the following expectation for countries that are under an IMF program:

$$
\begin{aligned}
E\left(Y_{1} \mid P=1\right) & =X_{1} \beta_{1}+E\left(\epsilon \mid G^{*}>0, I^{*}>0\right) \\
& =X_{1} \beta_{1}+\rho_{G} \sigma_{\epsilon} \lambda_{G}+\rho_{I} \sigma_{\epsilon} \lambda_{I}
\end{aligned}
$$

where $\lambda_{G}=\frac{\phi\left(\hat{G}^{*}\right)}{\Phi\left(\hat{G}^{*}\right)}$ and $\lambda_{I}=\frac{\phi\left(\hat{I}^{*}\right)}{\Phi\left(\hat{I}^{*}\right)}$ are the selection corrections for the government and the IMF interest in a program, respectively. For countries that are not under an IMF program, if we assume that the country did not choose to apply for a program, the expected growth rate is:

$$
\begin{aligned}
E\left(Y_{2} \mid P=0\right) & =X_{2} \beta_{2}+E\left(\epsilon \mid G^{*} \leq 0\right) \\
& =X_{2} \beta_{2}+\rho_{G} \sigma_{\epsilon} \lambda_{\sim G}
\end{aligned}
$$

parable to the bivariate probit specification that has been used in the literature (Vreeland, 2003), one needs to either assume that the stochastic components associated with IMF and Government's expected utilities have standard errors equal to $1 / \sqrt{2}$, or be aware that the estimated coefficients represent an estimate for the actual coefficients scaled by $\sqrt{2} \sigma$. This is akin to the problem of unidentified error variance in a probit model, where scholars either assume that $\sigma=1$ or estimate $\beta$ s scaled by $\sigma$ s. 
where $\lambda_{\sim G}=\frac{-\phi\left(\hat{G}^{*}\right)}{1-\Phi\left(\hat{G}^{*}\right)}$ is the selection correction for the lack of government interest. If, instead, the government wanted to participate in a program but was unable to reach an agreement with the IMF,

$$
\begin{aligned}
E\left(Y_{2} \mid P=0\right) & =X_{2} \beta_{2}+E\left(\epsilon \mid\left\{G^{*}>0, I^{*} \leq 0\right\}\right) \\
& =X_{2} \beta_{2}+\rho_{G} \sigma_{\epsilon} \lambda_{G}+\rho_{I} \sigma_{\epsilon} \lambda_{\sim I}
\end{aligned}
$$

where $\lambda_{\sim I}=\frac{-\phi\left(\hat{I}^{*}\right)}{1-\Phi\left(\hat{I}^{*}\right)}$ is the appropriate selection correction for this possibility.

Because of partial observability, when there is no program $(P=0)$, we cannot know whether the government did not seek one or the IMF was not interested in entering into a program with the government. Thus, we use the estimated probabilities for each observation from our selection model to decide whether to use equation 9 or 10 to calculate the selection corrections for the growth effects of participating in an IMF program. ${ }^{9}$

As Vreeland (2003) argues, the processes that determine program participation may depend on whether a country was already under a program in the previous year. We therefore separate the decisions to enter a new program spell and to continue to participate in a program, and estimate the transitions from one state to the other as a dynamic Markov process. We also correct for the potential effect of program duration for countries that are under a program, and non-program duration for countries that consider entering a new program.

\section{Results and Discussion}

The dataset covers all IMF members from 1970 to 2008, of which 104 countries are used for estimation. Descriptions of the variables used in our empirical analysis and their summary statistics

\footnotetext{
${ }^{9}$ This approach is superior, for example, to assuming that none of the countries that are not participating in programs applied for support, or that all applied but were rejected. Assigning countries to the most likely case takes advantage of the information we have about country choices from the strategic selection model, and allows us to estimate the differences between these two theoretically distinct groups of countries, which would otherwise bias our results.
} 
are presented in Tables 6 and 7. In addition, we performed the same analyses using the data from Vreeland's (2003) study on the effects of IMF programs on economic growth, which cover the years 1970-1990. ${ }^{10}$ More details about those results are available in the online appendix.

Table 1 presents estimation results from four models of program participation. All four are strategic probit MLE models, so the government's decision to apply for a program is modeled as a function of its expectation about the probability that the IMF will agree to such a program. The first two models utilize the data from Vreeland (2003) and span the years 1970-1990, and the second two use our extended data and span the years 1970-2008. The first and fourth columns present the results of analyses in which countries that are and are not currently under programs are pooled, which assumes that their governments' utilities and IMF utilities are not affected by their current program status. The remaining columns present the results of analyses that are performed separately for countries not under programs ("enter") and countries that are currently under programs ("remain"). The results indicate that the determinants of participation differ depending on prior program participation, so our preferred specifications estimate those decisions separately. On the other hand, our results are broadly consistent using the Vreeland (2003) data and our extended data. Except where otherwise indicated, the following discussion relies on the extended data and the separate estimation for entering and remaining under IMF programs.

[Table 1 about here.]

The results show that governments are more eager to enter a new IMF program when they have low levels of central bank reserves, high fiscal deficits and daunting debt service burdens. In addition, low levels of investment appear to make governments marginally more interested in applying for IMF programs. The 1970-90 data suggest that recent elections have the same effect, but this effect is not significant in the extended data. Furthermore, both sets of results find that the IMF is more willing to support countries with large balance of payments deficits in absolute terms - that is, imbalances that might be systemically disruptive. The earlier data suggest that the

\footnotetext{
${ }^{10}$ The Vreeland (2003) data and the extended data begin in 1951, but the estimation sample begins in 1970 because missing data cause the earlier decades to be eliminated by listwise deletion.
} 
IMF may be less willing to extend new loans when its resources are stretched thin by many other borrowers, but this result is only marginally significant in the extended data. The results from the early data also indicated that the IMF was more willing to approve programs for democratic countries, but this effect disappears in the extended data. The broad similarity of the results is reassuring.

To illustrate the substantive implications of our selection equation, in Figure 2 we graph the effects of variables that capture vulnerability to financial crises on governments' decisions to apply for IMF support: central bank reserves, fiscal balances (surplus/deficit) as a percentage of GDP, debt service as a percentage of GDP, and the balance of payments in billions of U.S. dollars. Each variable is normalized by its standard deviation to make the magnitudes comparable, and all other variables are held at their means. As central bank reserves increase, the probability that a government applies for a program steadily declines from about 0.5 at two standard deviations below the mean to 0.22 at two standard deviations above. Budget balance has a less dramatic effect in the range shown in the figure, but the data are highly dispersed, so very large deficits sharply increase the probability of applying for a program. As debt service ratios rise from two standard deviations below the mean to two standard deviations above, the probability of applying for an IMF program rises from about 0.15 to about 0.58. Because crisis variables tend to move in tandem - deficits, debt service ratios, balance of payments crises and dwindling reserves are linked through direct effects and market expectations - the total effect of financial crises largely determines government choices to apply for support.

[Figure 2 about here.]

The effect of the balance of payments on government choices is indirect; it does not appear in our government application equation. We assume, in fact, that the government is not concerned with the absolute size of its balance of payments, but worries instead about variables that are normalized by GDP and of more immediate policy concern. However, the benefit of estimating a strategic selection model is that we can identify the way in which a government's decision to apply for a program depends upon its expectations about whether the IMF will approve one. The 
IMF's decision is strongly affected by the applicant country's balance of payments, especially when the applicant is an important player in the international economy. Consequently, as the balance of payments deteriorates, countries are more likely to be approved. Indeed, countries that are not running payments deficits are highly unlikely to be granted an IMF program. We find that on average countries prefer not to apply rather than to apply and be rejected. As a result, the probability of applying decreases as the balance of payments improves.

Having analyzed the determinants of program participation, we are now in a position to analyze program effects. Table 2 presents the results of our growth regressions. Under each coefficient value, p-values are reported in parentheses. The table includes three models, each estimated with country fixed effects. The second model introduces a lagged dependent variable, and the third introduces year fixed effects in addition to country fixed effects. The results are consistent: the selection correction for the probability of Government participation is associated with negative growth outcomes, while the correction for IMF participation is associated with positive outcomes. The IMF evidently prefers to offer programs to countries that are likely to perform well, but the governments that are most interested in participating are those that are likely to perform poorly.

[Table 2 about here.]

Table 2 shows that all of the models reported estimate that the average treatment effect increased economic performance, and the average estimated benefit ranges from 1.36 percent of GDP in the baseline model to 3.46 percent of GDP in the model with year fixed effects. All three models estimate that the majority of participating countries enjoyed a positive benefit in terms of output, both according to the expected and gross estimated effect criteria. In the model with year fixed effects, that proportion rises to approximately three-quarters of participating countries.

Table 3 cross-tabulates the sign of the estimated benefit of an IMF program with the sign of the growth rate that program countries achieved. Of the 341 cases in which countries had positive growth under IMF programs, we estimate a positive effect of the program in 284 of cases. In the 172 cases where GDP declined under IMF programs, we estimate a negative effect of the program in 
59 cases. In the remaining cases where GDP declined, our model estimates that the IMF program nevertheless exercised a positive effect. These results indicate that the negative simple correlation (-.17) between participating in an IMF program and growth is caused by selection.

These findings are robust to a variety of regression specifications. Table 3 in the online appendix available at this journal's webpage includes nine additional specifications, including controls for life expectancy, education and birth rates and alternative measurements of the dependent variable. Table 4 in the appendix includes additional controls and explores the impact of missing data using a comparison model with multiple imputation. Table 2 in the appendix reproduces our main regression equations using the Vreeland (2003) data (1970-1990), and Table 8 presents eleven more specifications using those data that include additional control variables and alternative measures for the dependent variable. In all of the specifications considered, the average expected effect and average gross effect of IMF programs remained positive, and a majority of program participants are estimated to benefit from IMF agreements.

[Table 3 about here.]

Figure 3 presents the predicted effects of IMF program participation in the form of a histogram. ${ }^{11}$ There are a number of country years in which IMF programs are predicted to have negative effects, but the mass of the predictions lies in positive territory. There is significant dispersion of effects around the mean, which indicates that IMF programs have highly variable effects. Indeed, although the focus in the literature has been on establishing whether the mean effect of IMF programs is positive or negative, the variability of IMF program effects suggests that explaining the variation in these effects is more important. We turn to this issue next.

\section{[Figure 3 about here.]}

We argued above that the poor overall performance of IMF programs is due to adverse selection: countries that earnestly desire to participate in programs tend to be poor candidates for economic

\footnotetext{
${ }^{11}$ A similar histogram for the Vreeland (2003) data is presented as Figure 2 in the on-line appendix available at this journal's webpage.
} 
reform packages, and the countries that would be likely to succeed in implementing reform are least inclined to participate. We are now in a position to assess this claim quantitatively by comparing countries' propensity to participate in IMF programs with their expected program benefits. Figure 4 presents a quadratic regression fit of the estimated growth benefit on the estimated probability that the government consents to participate in a program. The figure shows a negative relationship between the government's estimated probability of seeking a program and the estimated growth benefit that it receives from one. This supports our adverse selection hypothesis: the countries that are most interested in participating in IMF programs are the least likely to have favorable growth outcomes.

[Figure 4 about here.]

We can further unpack the selection effect by investigating the indirect effects on growth of factors that make countries more likely to participate in IMF programs. Our model estimates that variables that measure the severity of a financial crisis increase the probability that a government seeks IMF assistance. Since we estimate that an increased probability of IMF program participation reduces the growth effect of an IMF program, we can attribute some of the reduced growth effect to those variables. Figure 5 graphs central bank reserves, debt service as a percentage of GDP, investment rates, and the budget balance (surplus/deficit) as a percentage of GDP against the estimated effect of an IMF program. The predicted benefits of IMF programs fall sharply as debt ratios rise, and increase sharply as a function of reserves and investment rates. The results for budget deficits look rather flat in the figure, but this is because the relevant range of this variable extends widely on both sides of the area shown. In each case, variables associated with the severity of financial crises motivate countries to seek aid from the IMF, but countries with weaknesses of these sorts are unlikely to perform well under IMF programs.

[Figure 5 about here.]

A few cases drawn from our data help to illustrate the logic of our model and spell out the 
indirect substantive effects on growth exercised by variables that affect participation in IMF programs. The Philippines participated in IMF programs in 1973 and in 1983, in both cases under the authoritarian regime of Ferdinand Marcos, who declared martial law in 1972. However, the Philippines acquired vulnerabilities between 1973 and 1983 that made it much less likely to perform well under an IMF program, and only some of these were visible to the visiting IMF Mission. In 1973 we estimate a moderately low probability of 31 percent that the Philippines would choose to participate in an IMF program, and we estimate a benefit from program participation of 0.58 percent of GDP. The Philippines was in a position to perform well economically in 1973 because it was not highly indebted, and it enjoyed rapid growth during the 1970s that was financed by substantial capital inflows. Under a series of IMF programs that lasted until 1982, the Philippines achieved average growth rates of 5.2 percent per year. However, the Marcos regime was very corrupt - Marcos himself is estimated to have embezzled some 15 billion dollars - and political stability was undermined by repression and social unrest. Marcos declared an end to martial law and prevailed in an election held in 1981, but only by engaging in overt fraud, and the major opposition parties boycotted the election. In 1982 the Philippines was one of few Asian countries that was swept up by contagion from the Mexican Peso crisis because it had run up substantial dollar-denominated debt. The Philippines' economic indicators had deteriorated by 1983, and we estimate a probability of 71 percent that the Philippines would turn to the IMF for support. The deficit rose from 2.2 percent of GDP in 1973 to 4.9 percent of GDP in 1983, debt service increased from 4.7 percent of GDP to 9.5 percent, the balance of payments moved from a surplus of 47 million dollars to a deficit of 69 million, and central bank reserves dropped from 4.3 months of imports to 1.8 months. Consequently, we estimate that a program initiated in 1983 would cost the Philippines 1.2 percentage points of GDP growth. Marcos was eager to obtain IMF financing to shore up his political fortunes, which were deteriorating as a result of his economic mismanagement. Only five months after signing a program with the IMF, Marcos apparently ordered the assassination of the opposition leader Benigno Aquino, which triggered a series of demonstrations that culminated in his removal from power in a peaceful popular uprising in 1986. The Philippines entered a recession in 1983, and GDP contracted by 8.6 percent in 1984 and by 4.7 percent in 1984 . The case of 
the Philippines illustrates the logic of adverse selection: by the time its leader was eager for IMF support, it was no longer a good candidate to benefit from it.

Gambia participated in IMF programs in 1977 and 1982, and again this was a case in which financial variables deteriorated in the interim. Gambia was a stable constitutional democracy in 1977 led by President Dawda Jawara, who won reelection five times. Gambia had relatively strong finances in 1977 for a poor African country, and we estimate that the probability that the government would choose to participate in a program was only 27 percent. This was a case with a negative estimated program benefit, where participation was estimated to cost Gambia half of one percent of GDP. Gambia enjoyed an average growth rate of 4.9 percent per year under IMF programs from 1977 to 1980. In 1981, however, a coup attempt destabilized the country and was only put down after Senegal intervened. This appears to have been a truly exogenous event: the coup took place in July 1981, when a leftist rebel, Kukoi Sanyang, took advantage of the fact that Jawara was in London to attend the wedding of Prince Charles and Lady Diana. During the crisis, the deficit rose from 2.7 percent of GDP to 12.3 percent and reserves fell from 3.3 months of imports to approximately one week. As a result, the restored Jawara government was desperate for IMF support, and we estimate a 68 percent chance of applying for a program in 1982. Under circumstances of high demand for support driven by political instability, the IMF loan had an estimated effect of reducing GDP by 2.6 percent. The Gambian economy continued to grow at a 1.4 percent rate in 1982 but collapsed in 1983, suffering a decline of 14 percent of GDP. Gambia formed a short-lived confederation with Senegal, but its political stability was shaken, and another coup overthrew the democratic regime in 1994. Gambia was never a strong candidate for IMF support, but its experience likewise illustrates the principle that a deterioration in economic fundamentals makes a country less likely to perform well under an IMF program.

A prominent unsuccessful case of IMF intervention was the effort to rescue Argentina from a financial collapse in 2001. The Argentine case has captured the popular imagination and led to a rallying cry against the IMF in Latin America, but it was not always so; in the early 1990s Argentina was a showcase example of the benefits of IMF-led macroeconomic stabilization. Argentina 
had suffered hyperinflation under Raul Alfonsin that reached 5,000 percent per year in 1989, and president Carlos Menem came to office prepared to take dramatic action to stabilize the economy and return to growth. After several false starts, in 1991 he appointed the former central banker Domingo Cavallo as his minister of finance with the assignment of taming inflation. Cavallo turned to the IMF for support, introduced the Convertibility Law, which fixed the peso at parity to the U.S. dollar, and ushered in a sweeping program of privatization. In 1991 our model estimates a probability of 0.67 that Argentina would apply for an IMF program and an expected growth benefit of 4.3 percent of GDP. The results were indeed positive: inflation was rapidly brought under control, foreign investment surged, and real GDP grew 10 percent in 1992, 6 percent in 1993, and 6 percent in 1994. A currency peg requires fiscal discipline to be sustainable, and in 1992 the Argentine budget was almost balanced; in 1993 it ran a small surplus. The government's commitment to austerity flagged as the economy recovered, however, and by 1995 the Argentine budget had moved into persistent deficit, which averaged over 3 percent of GDP for the rest of the decade. Debt rose from 29 percent of GDP in 1992 to 50 percent by 2000, and the cost of servicing the debt reached 9.9 percent of national income. Inflation caused a steady appreciation of the real exchange rate and a deterioration in the current account; in combination with mounting public debt, this made an eventual devaluation of the peso inevitable. However, President Fernando de la Rua, who succeeded Menem in 1999, was committed to retaining the fixed parity of the peso, which obliged him to seek further assistance from the IMF. As Figure 7 demonstrates, Argentina's demand for IMF support steadily rose throughout the 1990s and peaked at a 90 percent estimated probability of applying in 2001, while the estimated benefits of program participation steadily declined. Argentina received its largest IMF loan commitment of 17 billion SDRs in a program approved in 2000 and augmented at Argentina's request in 2001, but the accumulated debt had become so substantial that capital markets were not reassured, and in January 2002 the country faced a combined currency, banking and sovereign debt crisis. Riots forced the resignation of two presidents, and the economy moved into a deep recession.

[Figure 7 about here] 
Table 4 provides a number of quantitative examples from our data to illustrate the relationship between the predicted probability of government consent to participation in a program and growth outcomes. The expected growth effect is positive in cases in which the predicted probability of participation is moderate or low, and is negative in cases with high predicted probabilities. Moreover, these patterns track the actual growth outcomes with only a few exceptions. In cases where programs were initiated to stem the tide of financial crashes, as in Mexico in 1995 and Indonesia in 1998, the government was eager to participate because other policy alternatives had been exhausted. In each case, the predicted program effect is to depress growth, although the actual growth outcome is considerably worse than the effect that our model attributes to participation in an IMF program. Our model estimates that about one-third of the GDP decline in Mexico in 1995 and one-half of the decline in Indonesia in 1998 were due to their respective IMF programs. Political instability played an important role in both countries, and that is not captured in our model.

While these cases illustrate our finding that the effects of initiating IMF programs depend upon political context and the nature of the crises that compel countries to turn to the Fund for support, a separate question is how the effects of IMF programs vary between short-term and long-term participants. IMF financing was originally intended to address short-term balance-of-payments problems, but many countries draw repeatedly on IMF funds for many years, and it has been argued that long-term use of IMF resources is responsible for their poor track record. To the contrary, however, it could be the case that IMF programs exercise more positive effects over time because IMF Staff gradually fine-tune their policy prescriptions as they gain experience in-country, or because stabilization involves a trade-off of short-term adjustment for long-term performance, and structural reforms take time to bear fruit. In order to investigate the dynamics of how IMF programs affect growth rates over time, we estimate a quadratic regression of the estimated growth benefit on the duration of program participation. The resulting plot is presented in Figure 6 . The figure shows that the average expected program effect is significant and positive throughout, but steadily rises as the length of time a country has been under a program increases. This contradicts arguments about the harmful effects of recidivism, indicating that IMF programs have their most 
positive effects on growth after a country has already participated in programs for several years. The results are consistent with the interpretation that the increased benefits of participation come from a deepening of IMF Staff's understanding of local conditions, which ameliorates adverse selection problems.

[Figure 6 about here.]

These results do not mean that long-term users of IMF financing are fortunate countries with admirable growth trajectories. Quite to the contrary, the majority of long-term users are poor countries that suffer from economic mismanagement and political instability, and the fact that they return frequently to the IMF for support reflects these conditions. As we demonstrated above, the conditions that make these countries desperate for IMF support make them poor candidates to perform well. However, the adverse selection into the set of long-term users should not be confused with the treatment effect of long-term participation in IMF programs. Our results indicate that the average long-term user of IMF credit would have had economic performance that was considerably worse in the absence of IMF support. When we control for selection into programs and model the treatment effect as potentially variable, we find that the benefits of IMF programs are actually greater for countries that have participated for a number of years than for short-term participants. Intuitively, our results mean that countries that are under extreme stress require several years to receive the full benefits of participation in an IMF program. Furthermore, conditional on having been under a series of IMF programs, and being the kind of country that was likely to be under a series of programs in the first place, economic growth is likely to suffer more from exiting an IMF program than from continuing. The policy implications of our analysis of adverse selection are opposite those of the familiar moral hazard analysis. Rather than urging the IMF to curtail long-term engagement with developing countries, our analysis suggests that IMF Staff were in fact correct to believe that long-term engagement was beneficial. 


\section{Conclusions}

We argue that IMF programs appear to prevent rather than promote short-term economic growth because they suffer from adverse selection. The countries that offer the best prospects of successfully implementing IMF programs are least likely to apply. When the selection process is modeled in a way that explicitly allows for the possibility of adverse selection, the results demonstrate that IMF programs generally have beneficial consequences for short-term economic performance. This contradicts the received wisdom of the field, but is really unsurprising. IMF lending is intended to prevent financial, currency, or sovereign debt crises, which sharply reduce economic output when they occur. Furthermore, if programs did not have expected benefits, it is hard to explain why governments voluntarily participate in them. The results are statistically significant and substantively important, and indicate that IMF programs are less contractionary on average than the counterfactual in which they did not occur.

Our results, furthermore, have implications for an on-going debate within the Fund and outside about the policy implications of long-term use of IMF resources. Countries that use IMF resources are more likely to use them repeatedly, and the countries that do so include some of the poorest and worst-managed economies in the world. Using the standard logic of moral hazard, scholars and policy analysts have concluded that long-term use of Fund resources is detrimental to the development of these countries, and have encouraged the Fund to limit itself to its original purpose of providing short-term balance of payments assistance rather than long-term development assistance. The logic of adverse selection suggests the opposite analysis: repeat users of IMF programs would have had poor economic performance without programs as well, but the opportunity to interact with them repeatedly allows the Fund to overcome its information disadvantage and screen out the governments that are not making good-faith efforts to promote reform. Consequently, long-term users of Fund resources should benefit more on average from program participation than short-term users. Our empirical results demonstrate that this is, in fact, the case.

Our analysis suggests ways of mitigating the adverse selection problem, which should improve

the effectiveness of IMF programs over time. Each of these mechanisms relies upon efforts to 
separate worthy from unworthy borrowers. First, in order to mitigate adverse selection, it is essential that the credibility of Fund enforcement of conditionality increase. If conditionality is weakly enforced, it provides no incentives for governments that are not committed to reform to declare themselves by refusing to participate in IMF programs. Second, the Fund should mitigate the incentive for reform-averse governments to sign programs by front-loading conditionality in the form of prior conditions and back-loading the phasing of loan disbursements. Third, the Fund should increase the incentive for well-governed countries to participate in programs by raising the value of a Fund program as a signal to the market. This requires the IMF to be more selective in approving programs. A program cannot be a seal of approval if it is available to any member that wants one; and if it conveys no positive information to the market, it is likely to convey negative information.

Contrary to a substantial literature that has grown up to criticize the IMF, our analysis finds evidence that IMF programs have improved the economic performance of the majority of the countries that have participated in them. Furthermore, our findings indicate that it is possible to estimate which countries have benefitted and which have had their development stunted under IMF programs. In our analysis - as in the process of IMF program design and evaluation - the key factors that lead to success and failure are largely unobservable, and we can estimate them only because they have observable implications for which countries choose to apply for IMF assistance. If they were fully observable, adverse selection would be unproblematic. This indicates a fourth strategy for improving IMF program outcomes, which is to study the political factors that lead to program success and failure in order to reduce the degree of information asymmetry between the Fund and its members. 


\section{References}

Aggarwal, Vinod K. 1996. Debt Games: Strategic Interaction in International Debt Rescheduling. Cambridge: Cambridge University Press.

Akerlof, George A. 1970. "The Market for "Lemons"." Quarterly Journal of Economics 84(3):488500 .

Atoian, Rouben and Patrick Conway. 2006. "Evaluating the Impact of IMF Programs: A Comparison of Matching and Instrumental-Variable Estimators." Review of International Organizations 1:99-124.

Bauer, M. E., C. Cruz and A. T. Graham. 2012. "Democracies Only: When Do IMF Agreements Serve as a Seal of Approval?" Review of International Organizations 7:33-58.

Bird, Graham and Dane Rowlands. 2002. "Do IMF Programmes Have a Catalytic Effect on Other International Capital Flows?" Oxford Development Studies 30:229-49.

Bird, Graham, Mumtaz Hussain and Joseph P. Joyce. 2004. "Many Happy Returns? Recidivism and the IMF." Journal of International Money and Finance 23:231-51.

Blustein, Paul. 2001. The Chastening: Inside the Crisis that Rocked the Global Financial System and Humbled the IMF. New York: Public Affairs.

Cameron, Colin and Pravin Trivedi. 2005. Microeconometrics: Methods and Applications. New York, NY: Cambridge University Press.

Cooper, Richard. 1971. Currency Devaluations in Developing Countries. Princeton: Princeton University Press.

Copelovitch, Mark S. 2010. "Banks, Bonds, and Bailouts: The International Monetary Fund in the Global Economy.".

Eichengreen, B., P. Gupta and A. Mody. 2006. "Sudden Stops and IMF-supported Programs." NBER Working Paper. Cambridge, MA.

Frankel, Jeffrey. 2005. "Contractionary Currency Crashes in Developing Countries." NBER Working Paper No. W11508.

Goldstein, Morris. 1998. The Asian Financial Crisis: Causes, Cures and Systemic Implications. Institute for International Economics.

Goldstein, Morris and P. Montiel. 1986. "Evaluating Fund Stabilization Programs with MultiCountry Data: Some Methodological Pitfalls." IMF Staff Papers 33:304-44.

Gould, Erica. 2006. Money Talks: The International Monetary Fund, Conditionality, and Supplementary Financiers. Stanford: Stanford University Press.

Greene, William H. 2003. Econometric Analysis. Upper Saddle River, NJ: Prentice Hall.

Heckman, James. 1979. "Sample Selection Bias as a Specification Error." Econometrica 47:153-62. 
Hills, Carla A., Peter G. Peterson and Morris Goldstein. 1999. Safeguarding Prosperity in a Global Financial System: The Future International Financial Architecture. Washington, D.C.: Council on Foreign Relations and Institute for International Economics.

Independent Evaluation Office, International Monetary Fund (IEO). 2002. Evaluation of Prolonged Use of IMF Resources. Washington, D.C.: International Monetary Fund.

Ivanova, Anna, Wolfgang Mayer, Alex Mourmouras and George Anayiotos. 2003. "What Determines The Implementation of IMF-Supported Programs?" IMF Working Papers 03/8.

Jensen, Nathan. 2004. "Crisis, Conditions, and Capital: The Effect of International Monetary Fund Agreements on Foreign Direct Investment Inflows." Journal of Conflict Resolution 48:194-210.

Leblang, David. 2005. "Pegs and Politics." Working Paper.

Lipson, Charles. 1985. "Bankers' Dilemmas: Private Cooperation in Rescheduling Sovereign Debts." World Politics 38:200-25.

Maddala, G. S. 1983. Limited Dependent and Qualitative Variables in Econometrics. New York, NY: Cambridge University Press.

Meltzer, Allan H. 2000. "Final Report." International Financial Institution Advisory Commission (IFIAC or Meltzer Commission). http://www.house.gov/jec/imf/meltzer.pdf.

Mody, Ashoka and Diego Saravia. 2006. "Catalysing Private Capital Flows: Do IMF Programmes Work as Commitment Devices?" The Economic Journal 116:843-67.

Moser, Christoph and Jan-Egburt Sturm. 2011. "Explaining IMF Lending Decisions after the Cold War." Review of International Organizations 6:307-40.

Pop-Eleches, Grigore. 2009. From Economic Crisis to Reform: IMF programs in Latin America and Eastern Europe. Princeton, NJ: Princeton University Press.

Przeworski, Adam and James R. Vreeland. 2000. "The Effect of IMF Programs on Economic Growth." The Journal of Development Economics 62:385-421.

Signorino, Curtis S. 1999. "Strategic Interaction and the Statistical Analysis of International Conflict." American Political Science Review 93(2):279-97.

Signorino, Curtis S. and Kuzey Yilmaz. 2003. "Strategic Misspecification in Regression Models." American Journal of Political Science 47(3):551-66.

Steinwand, Martin and Randall W. Stone. 2008. "The International Monetary Fund: A Review of the Recent Evidence." Review of International Organizations 3:123-49.

Stiglitz, Joseph E. 2002. Globalization and Its Discontents. New York: Norton.

Stone, Randall W. 2002. Lending Credibility: The International Monetary Fund and the PostCommunist Transition. Princeton, NJ: Princeton University Press.

Stone, Randall W. 2008. "The Scope of IMF Conditionality." International Organization 62:589620 . 
Stone, Randall W. 2011. Controlling Institutions: International Organizations and the Global Economy. Cambridge: Cambridge University Press.

Sturm, Jan-Egbert, Helge Berger and Jakob de Haan. 2005. "Which Variables Explain Decisions on IMF Credit? An Extreme Bounds Analysis." Economics and Politics 17:177-213.

Vreeland, James R. 2003. The IMF and Economic Development. New York, NY: Cambridge University Press.

Vreeland, James R. 2006. "IMF program Compliance: Aggregate index versus policy specific research strategies." Review of International Organizations 1:359-78.

Woods, Ngaire. 2006. The Globalizers: The IMF, the World Bank, and Their Borrowers. Cornell University Press. 


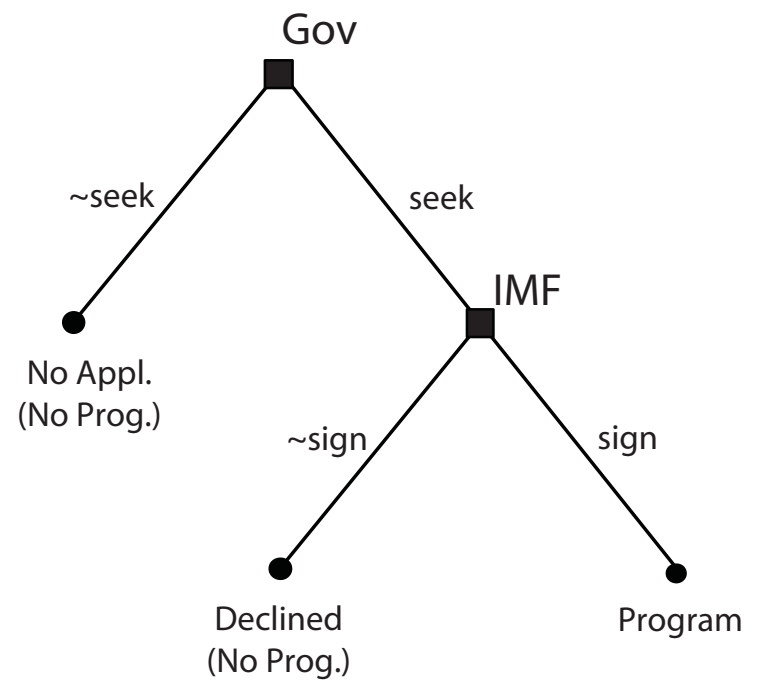

Figure 1: Strategic Selection into an IMF Program

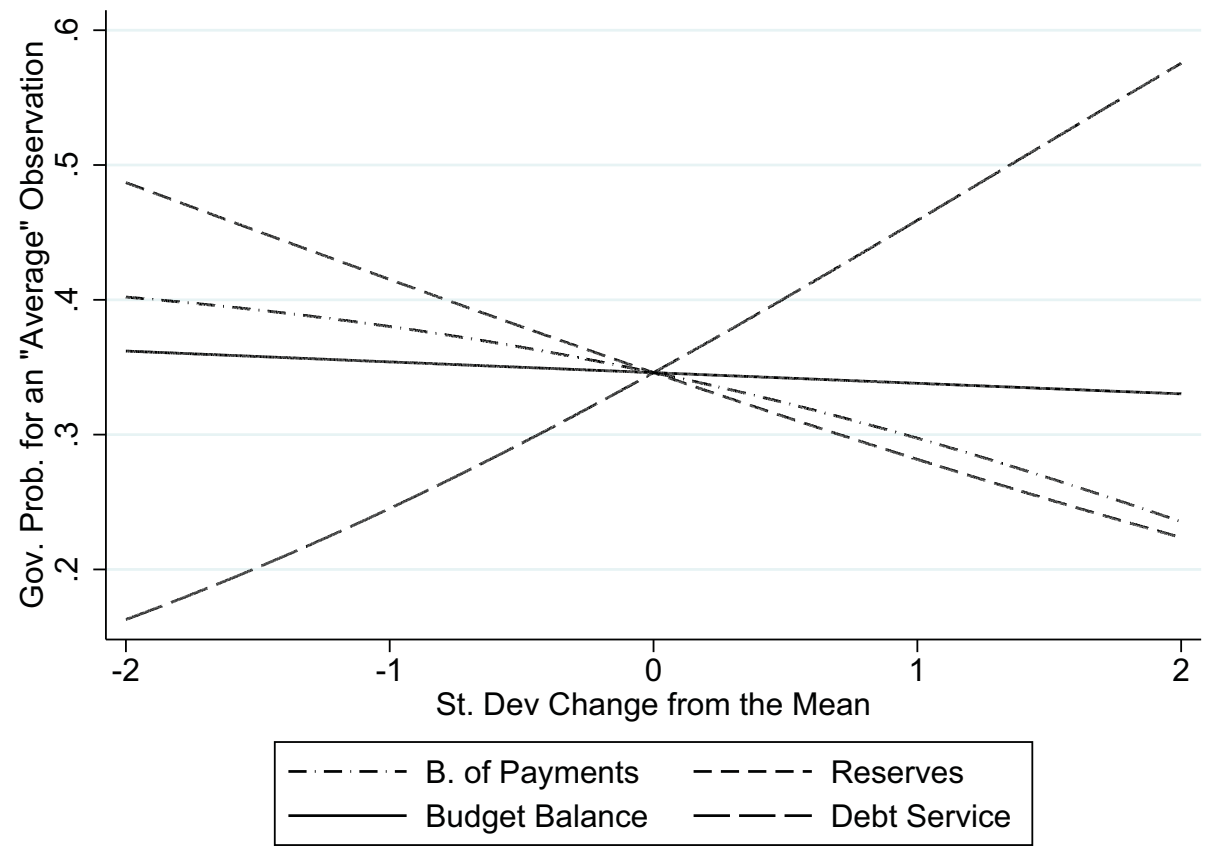

Figure 2: The Effect of Reserves, Balance of Payments, Debt Service and Budget Balance on the Government's Choice Probability 


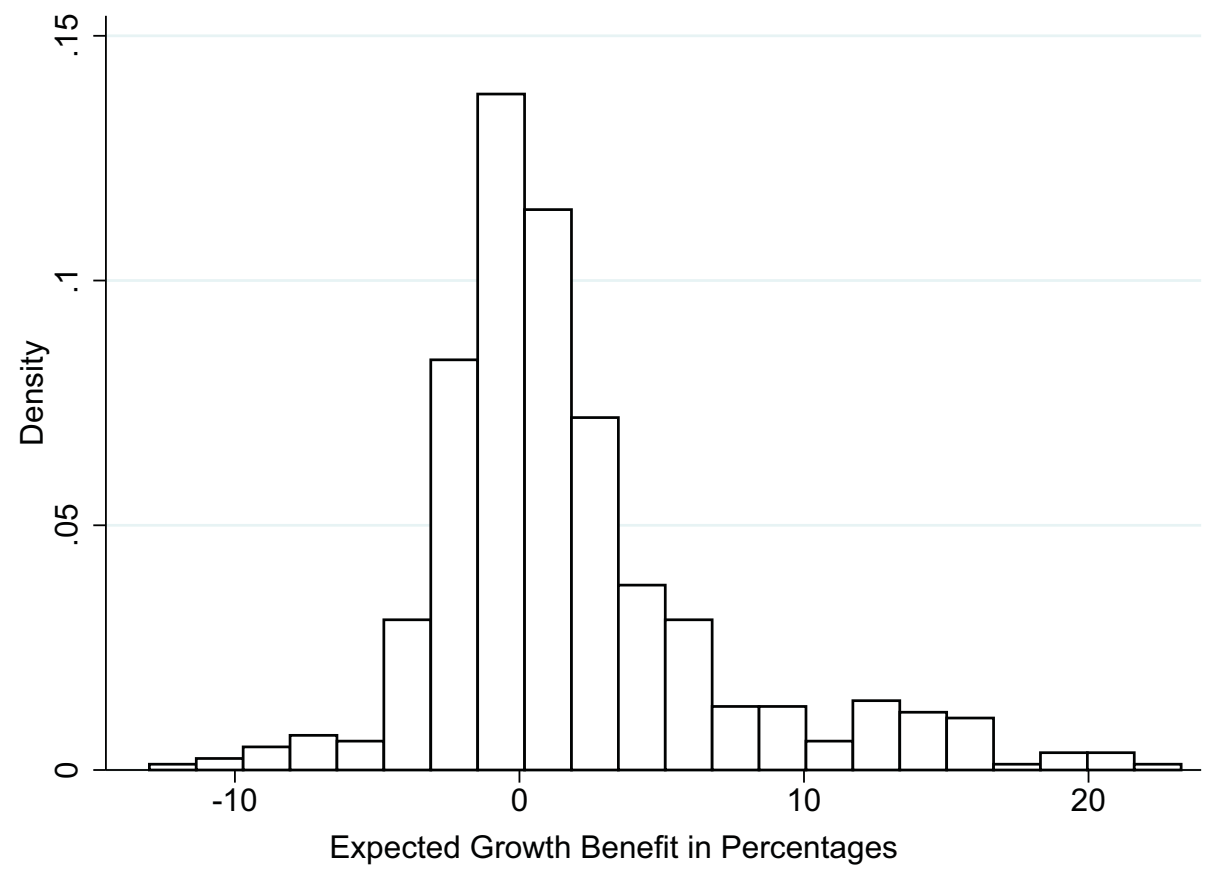

Figure 3: Estimated Growth Benefit for Countries in the Sample 


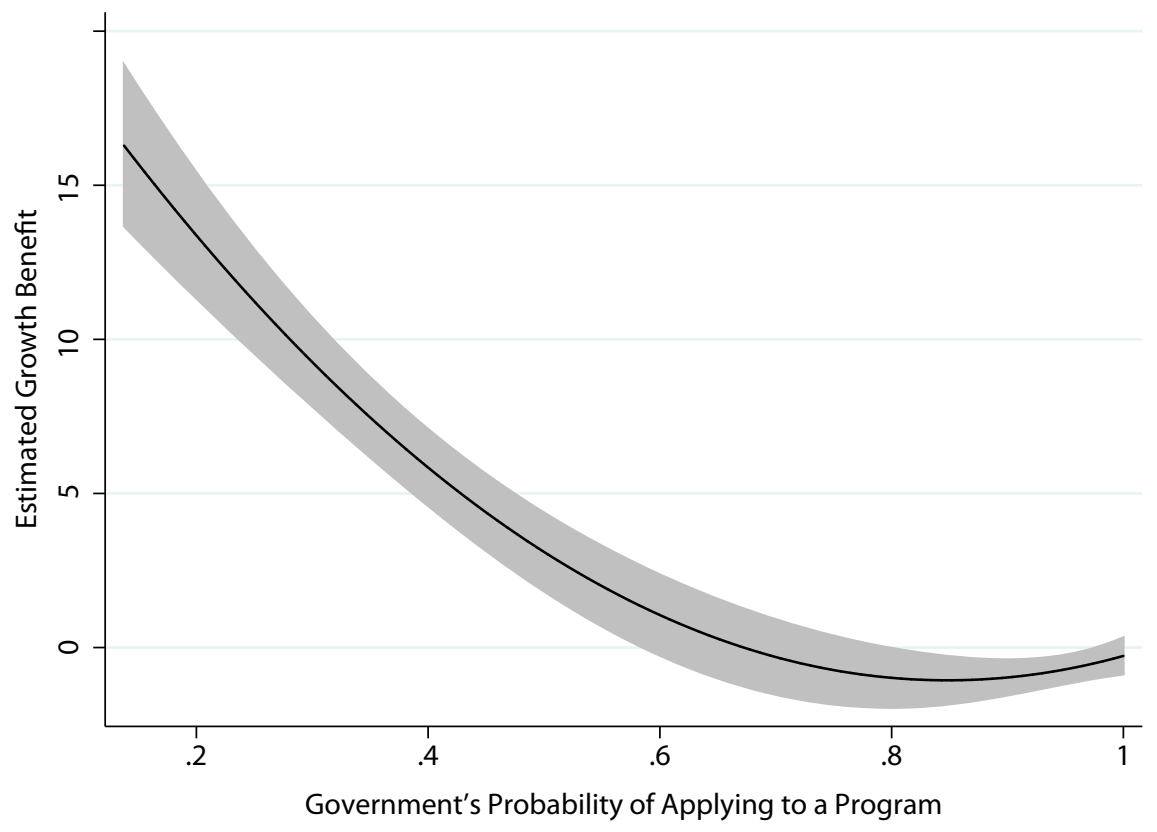

Figure 4: Quadratic Fit of Estimated Growth Benefit versus Government's Probability 


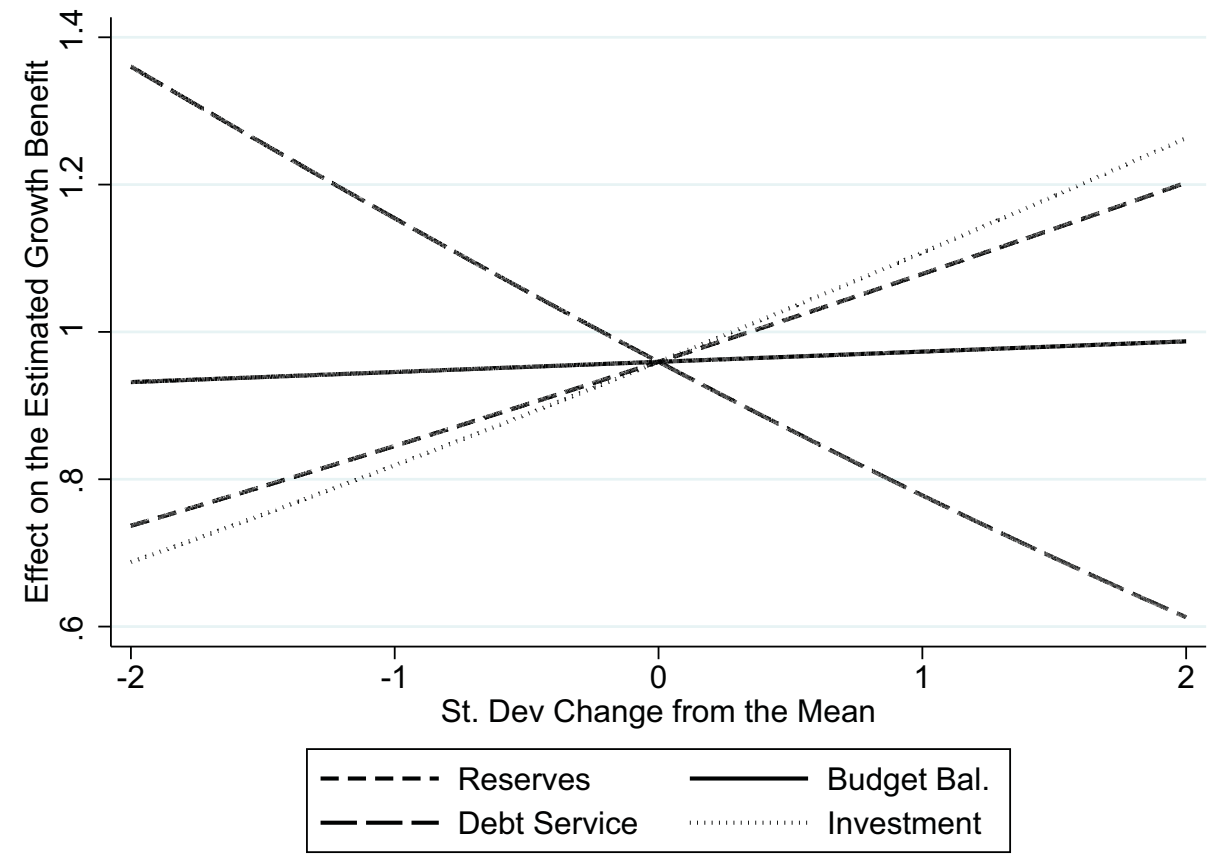

Figure 5: The Effect of Reserves, Debt Service, Investment and Budget Balance on the Estimated Growth Benefit of a Program Country 


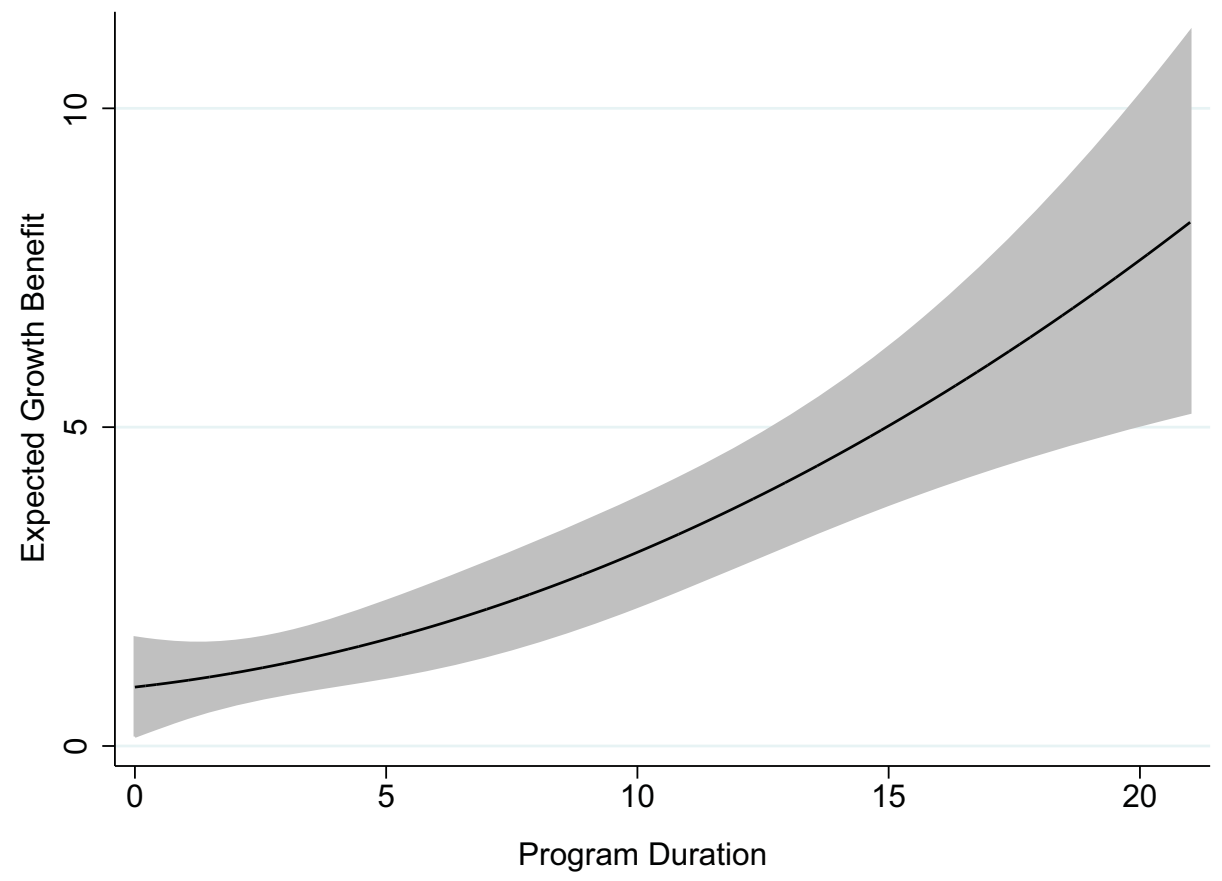

Figure 6: The estimated Effect of Program Duration on Growth Rates 


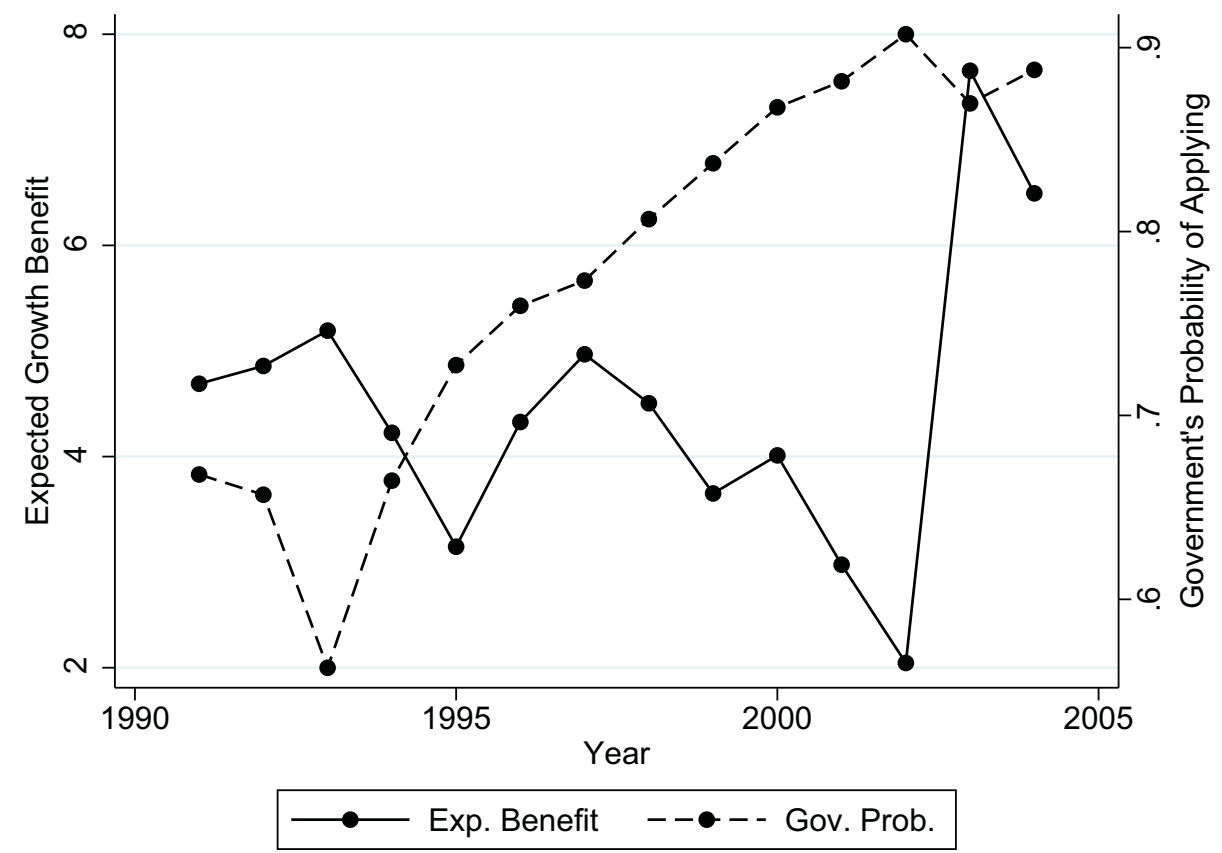

Figure 7: Predicted Probability of Applying and Estimated Growth Benefit for Argentina (19912004) 


\begin{tabular}{|c|c|c|c|c|c|c|}
\hline \multirow[b]{3}{*}{ Variable } & \multicolumn{6}{|c|}{ Government } \\
\hline & \multicolumn{3}{|c|}{ Years 1970-1990 } & \multicolumn{3}{|c|}{ Years 1970-2008 } \\
\hline & Pooled & Enter & Remain & Pooled & Enter & Remain \\
\hline \multirow[t]{2}{*}{ Reserves } & 2.183 & -1.945 & -.918 & -.059 & -.614 & .689 \\
\hline & $(.396)$ & $(.076)$ & $(.023)$ & $(.000)$ & $(.030)$ & $(.137)$ \\
\hline \multirow[t]{2}{*}{ Budget Bal. } & -11.294 & -3.179 & .106 & -.004 & -.186 & .020 \\
\hline & $(.004)$ & $(.000)$ & $(.383)$ & $(.648)$ & $(.103)$ & $(.765)$ \\
\hline \multirow[t]{2}{*}{ Debt Serv. } & 12.284 & 6.048 & .364 & .055 & .196 & .851 \\
\hline & $(.008)$ & $(.000)$ & $(.085)$ & $(.000)$ & $(.070)$ & $(.031)$ \\
\hline \multirow[t]{2}{*}{ Investment } & -6.048 & -2.086 & .114 & -.021 & -.054 & .020 \\
\hline & $(.013)$ & $(.003)$ & $(.424)$ & $(.000)$ & $(.074)$ & $(.669)$ \\
\hline \multirow[t]{2}{*}{ Years Under } & .049 & -.540 & .092 & .049 & .234 & -.033 \\
\hline & $(.976)$ & $(.428)$ & $(.623)$ & $(.000)$ & $(.076)$ & $(.494)$ \\
\hline \multirow[t]{2}{*}{ Num. Under } & 1.064 & .396 & -.099 & .001 & -.002 & -.088 \\
\hline & $(.337)$ & $(.280)$ & $(.483)$ & $(.749)$ & $(.933)$ & $(.095)$ \\
\hline \multirow[t]{2}{*}{ Lagged Elec. } & 14.804 & 5.630 & -.098 & -.051 & 1.36 & -1.676 \\
\hline & $(.009)$ & $(.000)$ & $(.644)$ & $(.589)$ & $(.315)$ & $(.064)$ \\
\hline \multirow[t]{4}{*}{ Constant } & 1.337 & 1.176 & 4.229 & -3.473 & -.134 & 32.78 \\
\hline & $(.860)$ & $(.635)$ & $(.000)$ & $(.408)$ & $(.854)$ & $(.035)$ \\
\hline & \multicolumn{6}{|c|}{ IMF } \\
\hline & \multicolumn{3}{|c|}{ Years 1970-1990 } & \multicolumn{3}{|c|}{ Years 1970-2008 } \\
\hline Variable & Pooled & Enter & Remain & Pooled & Enter & Remain \\
\hline \multirow[t]{2}{*}{ B. of Payments } & -1.710 & -12.444 & 2.808 & -.031 & -.228 & -.063 \\
\hline & $(.012)$ & $(.000)$ & $(.024)$ & $(.047)$ & $(.001)$ & $(.001)$ \\
\hline \multirow[t]{2}{*}{ Num. Under } & -.157 & -.268 & 1.453 & .028 & -.009 & -.001 \\
\hline & $(.211)$ & $(.007)$ & $(.015)$ & $(.108)$ & $(.128)$ & $(.918)$ \\
\hline \multirow[t]{2}{*}{ Regime } & .388 & .368 & -.120 & -.366 & .114 & -.054 \\
\hline & $(.037)$ & $(.096)$ & $(.822)$ & $(.083)$ & $(.483)$ & $(.613)$ \\
\hline \multirow[t]{2}{*}{ Constant } & -.505 & .471 & .925 & .612 & .094 & 1.144 \\
\hline & $(.349)$ & $(.436)$ & $(.689)$ & $(.393)$ & $(.813)$ & $(.000)$ \\
\hline $\mathrm{N}$ of Observ. & & & 1024 & 1496 & & \\
\hline Log-likelihood & & & -303.70 & -896.66 & & 81 \\
\hline
\end{tabular}

Table 1: Strategic selection into IMF Programs 


\begin{tabular}{|c|c|c|c|}
\hline & Model 1 & Model 2 & Model 3 \\
\hline Lagged Growth & & $\begin{array}{c}0.061 \\
(0.054)\end{array}$ & $\begin{array}{c}0.039 \\
(0.226)\end{array}$ \\
\hline Cap. Form. Gr & $\begin{array}{c}0.073 \\
(0.000)\end{array}$ & $\begin{array}{c}0.071 \\
(0.000)\end{array}$ & $\begin{array}{c}0.066 \\
(0.000)\end{array}$ \\
\hline Labor Force Gr. & $\begin{array}{c}-0.522 \\
(0.000)\end{array}$ & $\begin{array}{l}-0.517 \\
(0.001)\end{array}$ & $\begin{array}{l}-0.483 \\
(0.001)\end{array}$ \\
\hline Inflation & $\begin{array}{l}-0.118 \\
(0.052)\end{array}$ & $\begin{array}{c}-0.091 \\
(0.134)\end{array}$ & $\begin{array}{l}-0.096 \\
(0.125)\end{array}$ \\
\hline$\lambda_{G O V}$ & $\begin{array}{l}-0.026 \\
(0.037)\end{array}$ & $\begin{array}{l}-0.025 \\
(0.046)\end{array}$ & $\begin{array}{c}-0.006 \\
(0.667)\end{array}$ \\
\hline$\lambda_{I M F}$ & $\begin{array}{c}0.107 \\
(0.002)\end{array}$ & $\begin{array}{c}0.104 \\
(0.002)\end{array}$ & $\begin{array}{c}0.002 \\
(0.970)\end{array}$ \\
\hline Constant & $\begin{array}{c}0.079 \\
(0.124)\end{array}$ & $\begin{array}{c}0.075 \\
(0.144)\end{array}$ & $\begin{array}{c}0.043 \\
(0.409)\end{array}$ \\
\hline Country Dummies & Yes & Yes & Yes \\
\hline Year Dummies & No & No & Yes \\
\hline Average Growth Effect & 1.36 & 1.46 & 3.46 \\
\hline Expected \% & 58 & 60 & 77 \\
\hline Gross $\%$ & 57 & 58 & 72 \\
\hline$N$ & 927 & 925 & 925 \\
\hline
\end{tabular}

Table 2: Growth and IMF Programs using the Extended Data Set (1970-2008)

\begin{tabular}{rccl}
\hline \hline \multicolumn{4}{c}{ Est. Benefit } \\
Actual Gr. & Neg. & Pos. & Total \\
\hline Neg. & 59 & 113 & 172 \\
Pos. & 57 & 284 & 341 \\
Total & 116 & 397 & 513 \\
\hline \hline
\end{tabular}

Table 3: Estimated Growth Benefit and Actual Growth Rates for Countries Under a Program 


\begin{tabular}{|c|c|c|c|c|c|}
\hline $\begin{array}{l}\text { Country } \\
\text { Country }\end{array}$ & $\begin{array}{l}\text { COW } \\
\text { Code }\end{array}$ & Year & $\operatorname{Pr}_{G}$ (Apply) & $\begin{array}{c}\text { Est. Growth } \\
\text { Benefit }\end{array}$ & $\begin{array}{l}\text { Actual } \\
\text { Growth }\end{array}$ \\
\hline Uruguay & 165 & 2002 & .961 & -2.40 & -14.49 \\
\hline Mexico & 70 & 1995 & .877 & -2.95 & -9.02 \\
\hline Pakistan & 770 & 2001 & .861 & -2.77 & -1.21 \\
\hline Uruguay & 165 & 1998 & .837 & -.34 & 5.08 \\
\hline Philippines & 840 & 1993 & .826 & -1.34 & -.26 \\
\hline Indonesia & 850 & 1998 & .824 & -7.60 & -15.82 \\
\hline Gambia & 420 & 1990 & .798 & -1.34 & -1.45 \\
\hline Mali & 432 & 2004 & .746 & -2.91 & .77 \\
\hline Colombia & 100 & 2002 & .746 & -.51 & 1.08 \\
\hline Brazil & 140 & 1983 & .716 & -.52 & -5.87 \\
\hline Guatemala & 90 & 1990 & .706 & -1.32 & .94 \\
\hline Jordan & 663 & 1998 & .520 & 2.21 & -4.00 \\
\hline Uganda & 500 & 1987 & .495 & 7.25 & .77 \\
\hline Mozambique & 541 & 1988 & .468 & 15.98 & 7.80 \\
\hline Macedonia & 343 & 2005 & .467 & 15.81 & 3.22 \\
\hline Dominican R. & 42 & 1981 & .434 & .33 & 7.00 \\
\hline Nepal & 790 & 2004 & .369 & 9.35 & 1.68 \\
\hline Ethiopia & 530 & 1993 & .348 & 2.40 & 10.61 \\
\hline Thailand & 800 & 1981 & .283 & .46 & 6.34 \\
\hline Albania & 339 & 2003 & .249 & 20.31 & 11.98 \\
\hline Cape Verde & 402 & 2006 & .236 & 5.86 & 8.63 \\
\hline Lesotho & 570 & 1991 & .216 & 2.76 & -1.17 \\
\hline
\end{tabular}

Table 4: Probability of Applying and Estimated Growth Benefit

\begin{tabular}{rccl}
\hline \hline \multicolumn{3}{c}{ Actual Outcome } & \\
Pred. Outcome & No Program & Program & Total \\
\hline No Program & 483 & 233 & 716 \\
Program & 256 & 524 & 780 \\
Total & 739 & 757 & 1496 \\
\hline \hline
\end{tabular}

Table 5: Predicted vs. Actual Program Cases 


\begin{tabular}{|c|c|}
\hline Variable & Description \\
\hline Bal. of Payments & Overall balance of payments in billions of US dollars (IFS) \\
\hline Budget Bal. & Central government overall surplus as a percentage of the GDP \\
\hline Cap. Stock Gr. & Growth of capital stock per capita \\
\hline Debt Serv. & Total debt service ( $\%$ of GNP). \\
\hline Growth & The annual rate of growth of GDP \\
\hline Investment & $\begin{array}{l}\text { Real gross domestic investment (private and public) as a } \\
\text { percentage of GDP }\end{array}$ \\
\hline Labor Force Gr. & Annual rate of growth of labor force \\
\hline Lagged Elec. & $\begin{array}{l}\text { Dummy variable coded } 1 \text { if legislative elections were held } \\
\text { the previous country-year }\end{array}$ \\
\hline Num. Under & $\begin{array}{l}\text { Total number of other countries in the world currently under } \\
\text { an IMF agreement (excluding the given country itself) }\end{array}$ \\
\hline Regime & $\begin{array}{l}\text { Dummy variable coded } 1 \text { for dictatorships and } 0 \\
\text { for democracies }\end{array}$ \\
\hline Reserves & International reserves to imports of goods and services \\
\hline Under & $\begin{array}{l}\text { Dummy variable coded } 1 \text { for the country-years when there was } \\
\text { a conditioned IMF agreement }\end{array}$ \\
\hline Years Under & Cumulative number of years a country has been under IMF agreements \\
\hline
\end{tabular}

Table 6: Descriptions of the variables used in empirical analysis. 


\begin{tabular}{lccccc}
\hline \hline Variable & Observ. & Mean & St. Dev. & Min & Max \\
\hline Bal. of Payments & 4957 & .740 & 8.711 & -141.308 & 204.143 \\
Budget Bal. & 3105 & -2.171 & 6.225 & -202.696 & 40.434 \\
Cap. Stock Gr. & 4823 & 6.049 & 37.675 & -1923.492 & 723.202 \\
Debt Serv. & 3812 & 4.993 & 5.733 & 0 & 138.888 \\
Growth & 7434 & .024 & .074 & -.652 & 1.222 \\
Inflation & 5717 & 3.739 & 51.648 & -10 & 2441.103 \\
Investment & 7618 & 22.769 & 11.452 & -33.141 & 111.290 \\
Labor Force Gr. & 4549 & .023 & .020 & -.095 & .246 \\
Lagged Elec. & 8292 & .189 & .391 & 0 & 1 \\
Num. Under & 11297 & 38.030 & 20.064 & 0 & 75 \\
Regime & 8612 & .432 & .495 & 0 & 1 \\
Reserves & 4706 & 3.575 & 3.318 & -.092 & 43.693 \\
Under & 8447 & .261 & .439 & 0 & 1 \\
Years Under & 11297 & 4.235 & 7.307 & 0 & 41 \\
Year & 11297 & 1979 & 16.658 & 1950 & 2008 \\
\hline \hline
\end{tabular}

Table 7: Summary statistics of the variables used in empirical analysis. 